\title{
The nexus of tourism, renewable energy, income, and environmental quality: an empirical analysis of Pakistan
}

\author{
Sadia Bano ${ }^{1} \cdot$ Mehtab Alam² $^{2}$ Anwar Khan ${ }^{3}$ (D) Lu Liu ${ }^{1}$ \\ Received: 19 July 2020 / Accepted: 29 January 2021 / Published online: 11 February 2021 \\ (c) The Author(s), under exclusive licence to Springer Nature B.V. part of Springer Nature 2021
}

\begin{abstract}
In the current study, we investigate the dynamic association of tourism, renewable energy, income, foreign direct investment (FDI), and carbon dioxide $\left(\mathrm{CO}_{2} \mathrm{e}\right)$ for Pakistan over 1990-2017. We established four plausible hypotheses and verified by employing the autoregressive distributed lags model and Granger causality based on vector error correction model (VECM). Considering the cointegration relationship between the variables, the outcomes of autoregressive distributed lags suggested that tourism increases economic growth, and economic growth induces tourism in the long-run, thus confirming tourismled development, and growth-led tourism hypothesis; similarly, the tourism generates $\mathrm{CO}_{2} \mathrm{e}$ emissions, which supported the tourism-led emission hypothesis. The role of renewable energy consumption found to be a significant moderator, thus helping to enrich tourism, accelerating economic growth, and combating $\mathrm{CO}_{2} \mathrm{e}$ in the country. VECM causal results indicated the significant bidirectional causal linkages between tourism and economic growth - another causality found between tourism and $\mathrm{CO}_{2} \mathrm{e}$. There is one-way causality from FDI and renewable energy towards income simultaneously. Overall, the designers of policies will find this study useful for policymaking at government levels for smooth economic growth, investment, and sustainable tourism sector.
\end{abstract}

Keywords Autoregressive distributed lags · Renewable energy consumption - Sustainable tourism · Pakistan

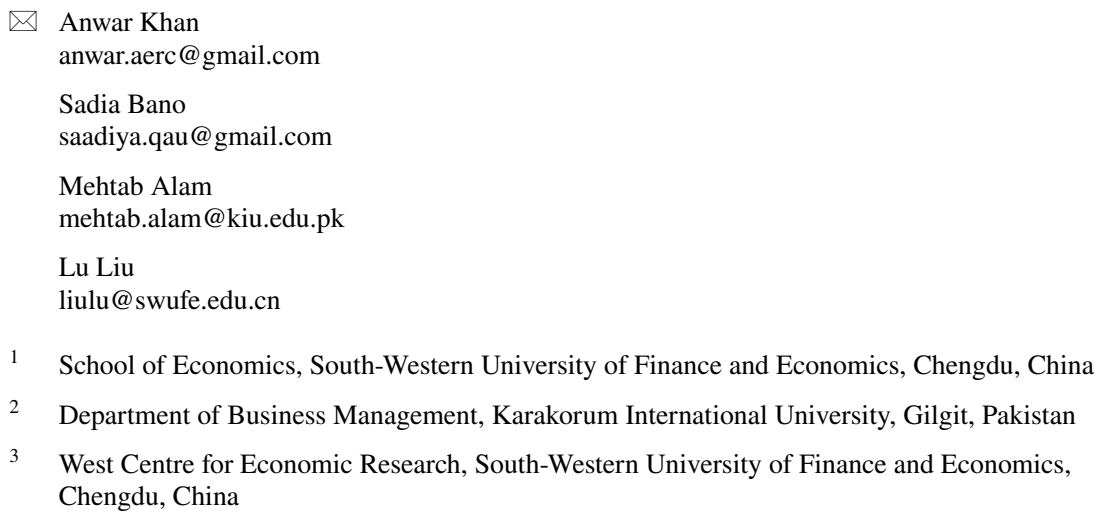

3 West Centre for Economic Research, South-Western University of Finance and Economics, Chengdu, China 


\section{Introduction}

In the growing world, every country wants to achieve a high pace of economic development; human activities to achieve economic growth are the responsible factors of environmental and ecological degradation (Uchiyama 2016; Zhou et al. 2015). The continuous increase of greenhouse gases like $\mathrm{CO}_{2}$ is the main element to increase earth temperature (IPCC 2013). The earth's temperature is multiplied by $0.9^{\circ} \mathrm{C}$ in the last two decades (Zhang and Liu 2019). Hence, identifying the major contributors to environmental degradation is the prime objective of the tables of environmental economists. Accordingly, the tourism sector is viewed as an essential part of local, regional, and national development and reconstruction of economies at different scales. The tourism sector is currently counted as the economic growth engine and source of cultural and heritage linkages. The tourism sector escalates economic growth and has a vital role, which has multiple ties with heterogeneous economic sectors, thus assisting through a positive multiplier effect and has the potential to acting as a catalyst for economic improvement (Vellas 2007). It contributes $10.2 \%$ to the world economy by creating and adding $9.9 \%$ jobs to the world job sector in 2016 (Tang et al. 2017; World Travel and Tourism Council 2018; Zhang and Liu 2019). Tourism contributes $6 \%$ to global merchandise and services exports; it accounts for $30 \%$ of international services trade. Its contribution to global GDP in 2014 was 9.8\% (Ohlan 2017). There is another aspect of tourism, which is habitat fragmentation, environmental degradation and ecological loss (Zaman et al. 2011). Unplanned growth in tourism has devastated the social, cultural, and natural environments of many destinations (Claudio et al. 2010; Zaman et al. 2011). Tang et al. (2017) found that the tourism sector accounts for $5 \%$ of the global $\mathrm{CO}_{2}$ emission. To address the significant impacts of tourism, it is required to make policies in support of making tourism as an essential contributor to UN sustainable development agenda. For the reasons above, the current study is conducted to test the relationship of tourism index based on three tourism variables with other possible actors, including $\mathrm{CO}_{2} \mathrm{e}$, income, renewable energy and FDI in Pakistan.

Discussion on sustainable tourism has been continued from the last two decades (Del Pablo-Romero and Molina 2013). In recent studies, the criticism on unbalanced development in tourism has seldom called into investigations based on global economic expansion, which escalates production and consumption of natural and non-natural goods simultaneously (Tiba et al. 2016). This human behaviour hinders the possibility of a sustainable development process globally. The global sustainable development agenda given by the United Nations has evoked a new layer of understanding in the tourism sector (Nepal et al. 2019). The other sectors focused on the "Sustainable development goals" by the UN are eliminating hunger, achieving food security, alleviating poverty, and combating climate change (UN 2017). The sustainable development goal (13) specifically addresses the sustainable tourism sector, reducing its impact on climate change, in-efficient use of fossil fuel energy, which is the primary source of environmental deterioration (Ben Jebli et al. 2019; Shaheen et al. 2019). The proper understanding of dynamic relationships between underlying economies, tourism, and the environment is crucial in making sustainable development policies. The empirical linkages testing such links are limited to the tourism sector (Nepal et al. 2019). Notably, in developing countries, where the main focus is to achieve economic growth based on the environment is crucial in the sustainable development process.

From the last two decades, Pakistan has suffered a lot in terms of fighting terrorism, environmental, and socio-economic crises that have emasculated the potential associated with the tourism industry of the country. Tourism is believed to be the potential indicator 
Primary energy by source

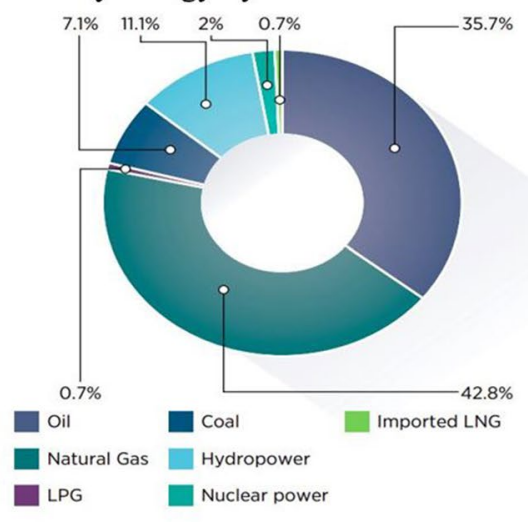

Final energy by source

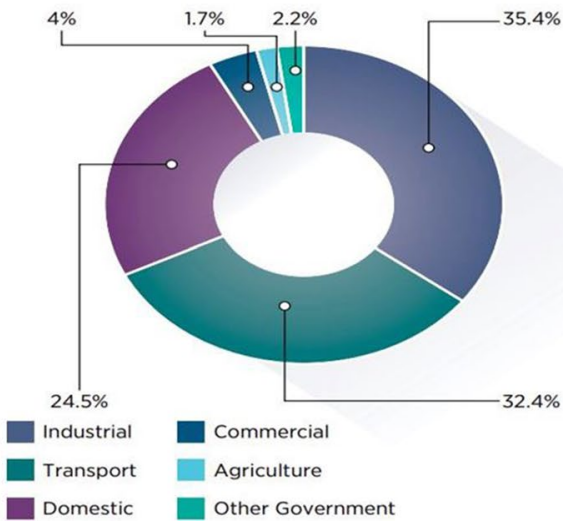

Fig. 1 Source of primary and final energy Source: Hydrocorbon Development Institute of Pakistan (2016)

to provide a basis for economic growth, efficient energy utilization, and environmental concerns. Regardless of these issues, Pakistan has given beautiful geographic locations, fascinating tourist sites and eye-popping potential by nature which attracts the tourist from across the globe (Adnan Hye and Ali Khan 2013; Meo et al. 2018). The receipts from Tourism in Pakistan are increasing gradually, for example, revenues from Tourism rose from 41 million in 1980 to 46 million in 1990, and this was expanded to 196 million in the last decade (Raza and Jawaid 2013). The total contribution to GDP from the tourism sector in Pakistan is calculated to be 7.4\% (US\$ 22,286 million) in 2017, which was expected to grow with $5.4 \%$ per annum to US\$ $39,851.6$ million in 2028 with $7.4 \%$ contribution to GDP of the country. The direct contribution of this sector to jobs was (1,493,000 jobs) 2.5\% of total employment in 2017 (World Travel and Tourism Council 2018). Here, the role of tourism in economic growth, employment, and expansion in production are enormous, while the substantial impression of tourism in the environment cannot be ignored. For example, the fossil-based consumption in transportation and hoteling have significant adverse effects on the environment (Koçak et al. 2020; Tsai et al. 2014). Therefore, the need is to switch towards alternative sources of energy sources in terms of energy conservation. Notwithstanding, Pakistan has abundant renewable resources that can be utilized to generate power for the industrial sector. Hydropower sector in Pakistan is considered the most potential and prominent and adds $11.1 \%$ of the primary energy source (IRENA $2018)^{1}$; this sector yet underexplored with a potential of $60 \mathrm{GW}$ (HDIP 2016). In that case, the significance of tourism, renewable energy, and environmental nexus in Pakistan cannot be neglected; therefore, the objective of this study is an attempt in this direction.

The main objective of the study is to test the impression of each $\left(\mathrm{CO}_{2} \mathrm{e}, \mathrm{Y}, \mathrm{TOR}, \mathrm{RE}\right.$, and FDI) independent variable in a system of five structural equations for Pakistan. Therefore, the study brings a vast knowledge into literature pool by adding; (1) this study integrates three tourism variables (tourist arrivals, tourist expenditures, and tourism receipts) into a single weighted index to disclose the relationship of tourism on the environment, economic growth, renewable energy, and FDI simultaneously. (2) The study introduces the

\footnotetext{
${ }^{1}$ The explanation of primary and final energy sources is given in Fig. 1 (source: HDIP 2016).
} 
recursive estimation of five separate equations (for $\mathrm{CO}_{2} \mathrm{e}, \mathrm{Y}, \mathrm{TOR}, \mathrm{RE}$, and FDI separately) to estimate the causal inferences, which will assist the policymakers in strengthening the economic and environmental policies centred on tourism and investment. (3) This study tests four central hypotheses (tourism/growth-led hypothesis, tourism-led emission, the positive association of tourism and renewable energy, and finally, FDI led tourism hypothesis) to acknowledge the expected relationships between the variables. (4) It adopts unitroots with breaks and cointegration test designed by Hatemi-J (2008) which is necessary step to test the data with breaks for each equation, therefore to conclude with unbiased and efficient results which arise due to structural shifts in macro-economic variables. Finally, "Vector error correction model (VECM) Granger causality" is estimated to detect the short, and long-run causal linkages between the chosen variables, which makes this research unique as compared to previous studies. Therefore, we firmly believe that this study would be an excellent help for policy guidance to seek balanced growth in tourism, economy and to curb environmental pollutants.

\section{Literature review}

There are existing studies that have discussed the distinct nature of tourism with various factors of the economic growth and environment that have not reached any encouraging outcomes. Mainly, the previous studies focus on tourism-led growth hypothesis. The econometric estimation used is quite variable based on the nature of the panel and timeseries data techniques. Therefore, this study has distributed the past literature on tourism, economic growth, FDI, renewable energy, and environment focusing on panel and time series econometrics. The reviews on time series data are limited, empirical estimations based on the time series estimation are contaminated with model selection biases and econometric methods used.

\subsection{Tourism and Growth}

A systematic literature review on indicators of tourism and economic growth is discussed in the work of (Del Pablo-Romero and Molina 2013). There is mix relationship explained between tourism and economic growth, including; economy driven tourism, tourism-led growth, bidirectional causality, and neutrality. The lack of consensus between the relationships between tourism and indicators of growth are inconclusive and still open for discussion. The pioneering work on tourism and economic growth in the tri-variate framework is conducted by Balaguer and Cantavella-Jordá (2002) for Spanish data over 1975-1997. His results were concluded with the long-run dynamic association between tourism and economic growth. In similar lines, the existence of a tourism push growth hypothesis is discovered in the study done by Vanegas and Croes (2003) for Aruba. Further, the research done by Durbarry (2004) explored the nexus of tourism and economic growth for Mauritania for 1950-1999 using Johansson cointegration, and VECM has found that tourism fostered economic growth. Similarly, Parrilla et al. (2007) established a cointegration relationship by using the data of Spain. Khalil et al. (2007) have explored two-way causal bonding between tourism and economic growth for Pakistan. Using Turkish data over 1963-2006, Kaplan and Celik (2008) have found one-way causality flowing from tourism to GDP growth. They suggested that tourism is a strategic sector that needs to be fostered in the long term. Similarly, the 
studies that have supported the existence of tourism lead growth are: Srinivasan et al. (2012) for Sri Lanka; Surugiu and Surugiu (2013) for Romania, and Tang and Abosedra (2014) in case of Lebanon are worth noting.

On the other hand, Ekanayake and Long (2012) have negated the tourism-led growth hypothesis by testing the data for 140 countries and six regions across the world for 1995-2009. In the case of Malaysia, Tang (2011) explored the growth-induced tourism hypothesis. In similar lines, bi-directional causality detected between tourism and economic growth by Apergis and Payne (2012) for nine Caribbean countries. Summarizing the discussed literature, we establish a positive hypothesis between tourism and economic growth in the case of Pakistan (Hypothesis-1).

\subsection{Tourism and Environment}

This group of research discusses the recent literature on the relationship between the environment and tourism. Like, UNWTO (2008) has estimated that tourism-related $\mathrm{CO}_{2}$ emission contributes to $5 \%$ of global $\mathrm{CO}_{2}$ emission. They explained that this emission generated due to the travelling of tourists through aeroplanes, buses, and cars, etc. The contribution of the tourism sector to $\mathrm{CO}_{2}$ is substantial and cannot be neglected. Studying the data of ten Northeast and South-East Asian countries, Zhang and Liu (2019) found that improving tourism growth in the long-run can help regenerate environmental facilities; however, tourism is seen as a critical aspect of the environment in this area. They (Zhang and Liu 2019) said that in some individual countries, the increase in tourism had shown improvements in the environment. Lei and Jing (2016) explored that tourism and environmental degradation have a negative impact in eastern China; the results supported the existence of short- and long-run causality from tourism to $\mathrm{CO}_{2}$ emission for China. In the case of Cyprus, Katircioglu et al. (2014) presented that tourism has a long-run positive and stable relationship with $\mathrm{CO}_{2}$, it is found to be a degrading factor of the environment in Cyprus. Shakouri et al. (2017) described tourism as a significant contributor to tourism to $\mathrm{CO}_{2}$ emissions by using GMM for a panel of Asia Pacific countries from 1995 to 2013. They also revealed (Shakouri et al. 2017) that a unidirectional causality for the research area was again flowing from $\mathrm{CO}_{2}$ emissions to tourism. Testing the data for Malaysia Solarin (2014) using the ARDL model from 1972 to 2010 showed that tourist arrivals and $\mathrm{CO}_{2}$ emissions have a long-term positive relationship. Using panel data for 1995-2010, Ben Jebli et al. (2015) revealed that tourist arrivals and energy use have adverse effects on the environment in Tunisia; however, the results were not similar for the panel in the long-run case, as tourism helps to combat $\mathrm{CO}_{2}$ emission. Lin et al. (2019) survey 1057 respondents in Taiwan and expressed that people who have a high income, education, and taking benefit from Tourism have positive perceptions about tourism on sustainable development and respondents having a low salary, low education, and low gains have contrary opinions. Zaman et al. (2016a; b) also examined in a panel of regions including European Union, OECD, East Asia, and Pacific, and Non-OECD countries over 2005-2013 indicated that Tourism is the inducing agent of $\mathrm{CO}_{2}$; also they revealed that Tourism is causing an environment in these regions. Regarding the relationship between Tourism and environment, most of the available studies have shown a positive relationship with $\mathrm{CO}_{2}$ emission. There are, however, a few who find the opposite connection between tourism and the climate (Lee and Brahmasrene 2013; Shakouri et al. 2017). Concluding from the reviewed literature, we expect to have a positive association between $\mathrm{CO}_{2} \mathrm{e}$ and tourism in the case of Pakistan (Hypothesis-2). 


\subsection{Tourism and renewable energy}

Worldwide, tourism has been attributed as the contributor of global $\mathrm{CO}_{2} \mathrm{e}$ emitter due to its intensive energy consumption in transportation and hoteling (Solarin 2014). Existing studies, which have performed to explore the intensive use of energy, are interlinked with detrimental impacts on the environment (Isik et al. 2018). Previous studies on the relationship between renewable energy and tourism are scant; there are a few studies, for example, by Ben Jebli et al. (2019) have disclosed bidirectional long-run causality between renewable energy and tourism. Similarly, using the panel data of region-wise Asian economies, Zhang and Liu (2019) have identified a unidirectional causal link between tourism and renewable energy consumption for Northeast and Southeast Asia; Southeast Asian countries. From the previous studies on tourism and renewable energy, we propose to have a positive association between the two variables (Hypothesis-3).

\subsection{Tourism and FDI}

In time series analysis, there are no much studies, which have explained the linkages between foreign direct investment and tourism. Using a multivariate framework for Iran, Khoshnevis Yazdi et al. (2017) narrated that FDI is one of the factors augmenting the tourism sector; however, they have found no causal relationships in using ARDL and vector error correction model framework. Besides, testing the data of Malaysia, Alam et al. (2015) have explored the existence of long-run linkages between tourism and FDI. Similarly, in a bivariate framework, Gaadar et al. (2016) have found short- and long-run relationships between FDI and tourism in the case of Saudi Arabia. Selvanathan et al. (2012) explored bidirectional causal relationships between FDI and tourism using the VAR framework in India. Besides, Fereidouni and Al-mulali (2014), using panel cointegration and Granger causal test, have confirmed the cointegrating association and bidirectional causality between tourism and real estate FDI for OECD countries. Similarly, development in the tourism sector in Nepal has suggested improving more capital investment (Nepal et al. 2019). Based on the above literature, we develop the fourth hypothesis that tourism and FDI have a positive association in the case of Pakistan (Hypothesis-4).

Mentioning the practical outcomes of many studies across the globe inferred that the simultaneous linkages between TOR, Y, $\mathrm{CO}_{2} \mathrm{e}, \mathrm{FDI}$, and $\mathrm{RE}$ are far being investigated. Therefore, the current research uses relatively new econometric techniques by incorporating structural breaks and cointegration with regime shifts to examine the relationship between ecological footprints with TD, real GDP, and FDI for Pakistan.

\section{Data and methods}

To delve into significant insights for the short and long run across the variables including carbon dioxide emission $\left(\mathrm{CO}_{2} \mathrm{e}\right)$, renewable energy percentage of total energy consumption (RE), FDI (inflows at current US\$), Real GDP (constant at 2010 US\$) denoted with (Y) and the index of three tourism (TOR) indicators (tourism expenditures, tourism receipts, number of tourist arrivals annually). Figure 2 displays the trends of the chosen variables based on five-year averages; the linear upward trend specification of the data indicates the growing path of each variable in the study period in the case of Pakistan. Following 


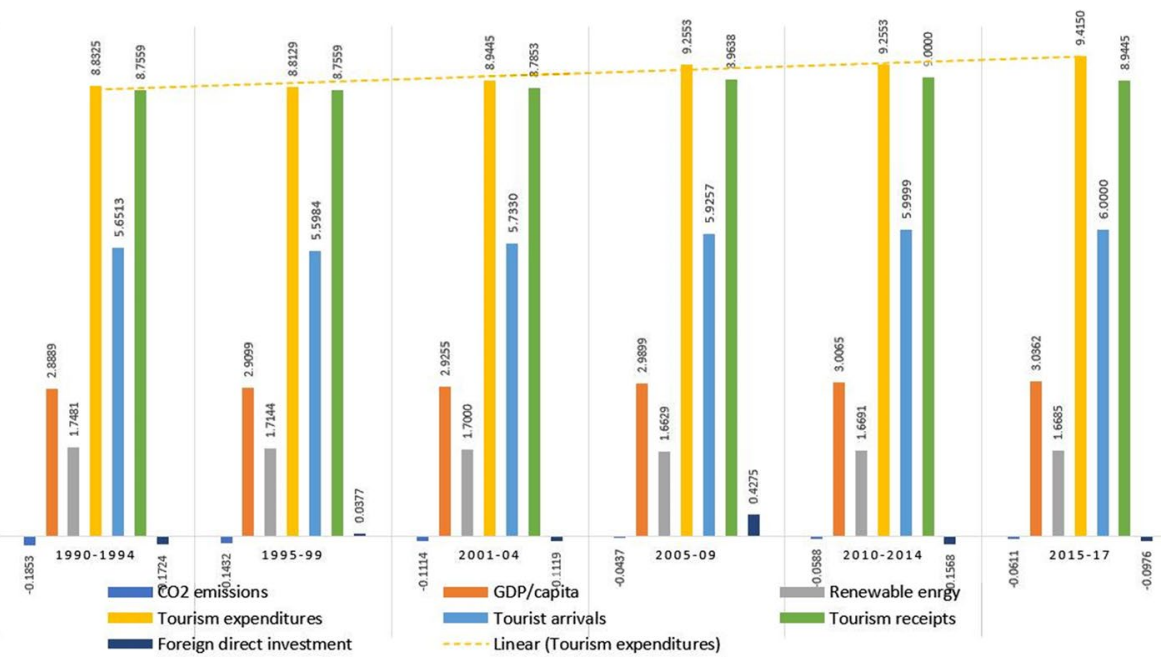

Fig. 2 Plots of the variables

the study of Fareed et al. (2018), we collected the data on Pakistan from the World Bank (2018), by considering the data availability on indicators of tourism variables, the period is examined for time 1990-2017. Some of the missing values for tourism variables were filled by using forward and backward interpolation for the robust inference by following Zaman et al. (2016a; b) and Bhuiyan et al. (2018). By studying the time-series nature of data, variables are converted into logarithm before further analysis. The next section describes the tourism index and outlines the methodology. The data and the econometric methods are the primary basis to test the above-highlighted hypothesis.

\subsection{Principal component analysis}

In the multivariate data, principal component analysis (PCA) is considered one of the favourite dimension reduction techniques. The benefits of PCA, the most variation in multidimensional data sets is explained with small elements of data sets called principal components. This was introduced in 1901 by Pearson, improved by Hotelling (1933) and reached heights after the work of Jolliffe (1986), who introduced the whole methodology systematically. Recently, the work is started using in environmental and sustainable economics studies (Mamipour et al. 2019; Zaman et al. 2016a, b). The method is explored to other fields of research (Biology, Economics, Chemistry, etc.) as well (Li et al. 2016). This study develops an index using PCA for three indicators of tourism for Pakistan. The indicators include tourist arrivals, tourism expenditure, and tourism receipts. Using PCA, we develop a weighted index for tourism that combines all three indicators of tourism in a single index. Table 1 (Components) explores the results of PCA; the value of the Eigen for the first factor is 2.7405 , where the second factor is 0.2033 , and for the third factor, it is 0.0561 simultaneously. The first component explains the associated proportion is maximum, i.e. 91.35\%. Table 1 (Eigen-vectors) illustrates the factor loadings for each element. The first component has comparatively large value than component two and three. Therefore, we have used the first component to construct the index for tourism demand. Finally, Table 1 (Correlation) indicates there is a correlation between the three variables; thus, tourist 
Table 1 Result of principal component analysis

\begin{tabular}{llll}
\hline & Eigen values & Difference & Proportion \\
\hline (a) Components & & & \\
Component 1 & 2.7405 & 2.5371 & 0.9135 \\
Component 2 & 0.2033 & 0.1472 & 0.0678 \\
Component 3 & 0.0561 & & 0.0187 \\
(b) Eigen-vectors & & & \\
TAR & 0.5909 & -0.2093 & -0.7791 \\
TEX & 0.5627 & 0.7990 & 0.2121 \\
TRP & 0.5781 & -0.5637 & 0.5900 \\
(c) Correlation & & & \\
Variables & TAR & TEX & TRP \\
TAR & 1 & & \\
TEX & 0.8680 & 1 & 1 \\
TRP & 0.9344 & 0.8069 & \\
\hline
\end{tabular}

Scree plot

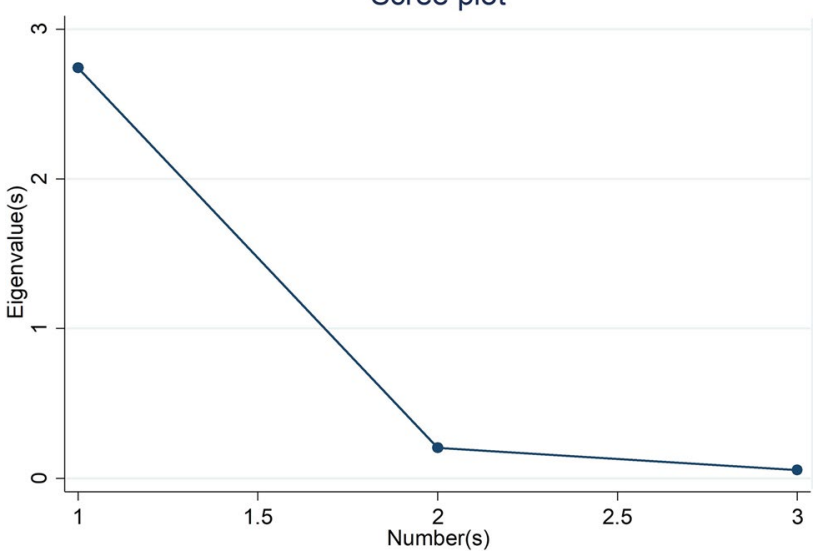

Fig. 3 Scree plot

arrivals, tourism expenditure, and tourism receipts have a considerably significant correlation for Pakistan. The information is also clear from the scree plot in Fig. 3, which explains that most of the proportion of the data is defined by component one of the three variables. It shows that the maximum eigenvalue for the first component is 2.74 which explains the data about $94.35 \%$, and the second component has 0.2033 (the kinked point at the scree plot) eigenvalues, which only able to explain $6.78 \%$ of the proportion of data, which is relatively less. Therefore, it is sufficient to select the first component of the PCA to make a composite index of tourism development for Pakistan.

\subsection{Empirical settings}

The fundamental question to be answered in the following study is " What is the relationship between tourism development, renewable energy consumption, FDI, income and $\mathrm{CO}_{2} \mathrm{e}$ 
for Pakistan when the tourism receipts improve economic growth?" keeping this question in mind, we specify recursive models for $\mathrm{CO}_{2} \mathrm{e}$, renewable energy consumption, FDI, tourism development and GDP. To the theoretical relevance of the taken variables, the indicator of environmental degradation in terms of $\mathrm{CO}_{2}$ emissions, and real GDP is obtained from the study of (Shah et al. 2019; Sun et al. 2020), where the theoretical relevance of getting the tourism variables in the current study are coming from (Zaman et al. 2016a, b); similarly, the FDI inflows are obtained in line with (Ahmad et al. 2020). Finally, renewable energy is taken from the study of (Ben Jebli et al. 2019).

By going through the literature, we have witnessed that the nexus of the environment with various factors of degradation have been examined with time series autoregressive distributed lags (ARDL) methods along with Granger causality followed by error correction models. They have assumed the regime shifts the nature of data by neglecting the asymmetric effects of variables across the time. The current research uses a linear ARDL model developed by "Pesaran et al. (1999) and Pesaran et al. (2001)" to detect structural breaks if any in the data by integrating the dummy variables. To establish the long-run dynamics of $\mathrm{CO}_{2} \mathrm{e}, \mathrm{Y}, \mathrm{FDI}$, renewable energy and tourism demand by allowing for the pollution haven framework for Pakistan, the linear functional form can be of the following order for the five models;

$$
\begin{gathered}
\mathrm{COe}_{2, t}=\vartheta_{0}+\vartheta_{1} \mathrm{Y}_{t}+\vartheta_{1 a} \mathrm{Y}_{t}+\vartheta_{2} \mathrm{TOR}_{t}+\vartheta_{3} \mathrm{RE}_{t}+\vartheta_{4} \mathrm{FDI}_{t}+\mu_{t} \\
\mathrm{Y}_{t}=\vartheta_{0}+\vartheta_{1} \mathrm{RE}_{t}+\vartheta_{2} \mathrm{TOR}_{t}+\vartheta_{3} \mathrm{COe}_{2, t}+\vartheta_{4} \mathrm{FDI}_{t}+\mu_{t} \\
\mathrm{TOR}_{t}=\vartheta_{0}+\vartheta_{1} \mathrm{Y}_{t}+\vartheta_{2} \mathrm{RE}_{t}+\vartheta_{3} \mathrm{COe}_{2, t}+\vartheta_{4} \mathrm{FDI}_{t}+\mu_{t} \\
\mathrm{RE}_{t}=\vartheta_{0}+\vartheta_{1} \mathrm{Y}_{t}+\vartheta_{2} \mathrm{TOR}_{t}+\vartheta_{3} \mathrm{COe}_{2, t}+\vartheta_{4} \mathrm{FDI}_{t}+\mu_{t} \\
\mathrm{FDI}_{2, t}=\vartheta_{0}+\vartheta_{1} \mathrm{Y}_{t}+\vartheta_{2} \mathrm{TOR}_{t}+\vartheta_{3} \mathrm{COe}_{2, t}+\vartheta_{4} \mathrm{RE}_{t}+\mu_{t}
\end{gathered}
$$

$\mathrm{CO}_{2} \mathrm{e}$ is used for environmental degradation, $\mathrm{Y}$ is the real gross domestic product, TOR expresses tourism demand based on a composite index of three tourism variables, and FDI indicates foreign direct investment. $\vartheta_{1,2,3,4}$ are unknown parameters of the independent variables to be estimated, and $\mu_{t}$ is the error term of the regression.

\subsection{Specification of econometric models}

\subsubsection{ARDL bound testing}

In this study, we used a much appropriate and unique method of ARDL cointegration, which has statistical superiority over other cointegrating techniques (Pesaran et al. 2001). This estimator has an advantage over other techniques; for example, ARDL gives robust results in endogeneity and autocorrelation by enabling the researchers to provide short- and long-run effects at the same time. This is an appropriate technique for I(1), I(0), and mixed of integration other than I(2) series. Due to its small sample properties, it gives efficient and consistent results; similarly, different lag lengths are used for different variables in the model based on many lags selection criteria (Rahman and Kashem 2017). Considering the breaks in the data, the cointegration relationship among the variables will be estimated 
following Shin et al. (2014) ARDL models by incorporating the dummy variables to detect the structural breaks;

$$
\begin{aligned}
\Delta \mathrm{CO}_{2} \mathrm{e}_{t}= & \tau_{0}+\sum_{b=1}^{p} \tau_{1} \Delta \mathrm{CO}_{2} \mathrm{e}_{t-b}+\sum_{b=1}^{p} \tau_{2} \Delta \mathrm{Y}_{t-b}+\sum_{b=1}^{p} \tau_{3} \Delta \mathrm{Y}_{t-b}^{2}+\sum_{b=1}^{p} \tau_{4} \Delta \mathrm{RE}_{t-b}+\sum_{b=1}^{p} \tau_{5} \Delta \mathrm{TOR}_{t-b} \\
& +\sum_{b=1}^{p} \tau_{6} \Delta \mathrm{FDI}_{t-b}+\sum_{b=1}^{p} \tau_{7} \Delta \mathrm{D}_{t-b}+\pi_{1} \mathrm{Y}_{t-j}+\pi_{2} \mathrm{Y}_{t-j}^{2}+\pi_{3} \mathrm{RE}_{t-j}+\pi_{4} \mathrm{TOR}_{t-j}+\pi_{5} \mathrm{FDI}_{t-j} \\
& +\pi_{6} \mathrm{CO}_{2} \mathrm{e}_{t-j}+\vartheta \mathrm{ECT}_{t-j}+\beth_{t} \ldots \\
\Delta \mathrm{Y}_{t}= & \tau_{0}+\sum_{b=1}^{p} \tau_{1} \Delta \mathrm{Y}_{t-b}+\sum_{b=1}^{p} \tau_{2} \Delta \mathrm{RE}_{t-b}+\sum_{b=1}^{p} \tau_{3} \Delta \mathrm{TOR}_{t-b}+\sum_{b=1}^{p} \tau_{4} \Delta \mathrm{CO}_{2} \mathrm{e}_{t-b}+\sum_{k=1}^{p} \tau_{5} \Delta \mathrm{FDI}_{t-b} \\
+ & \sum_{b=1}^{p} \tau_{6} \Delta \mathrm{D}_{t-b}+\pi_{1} \mathrm{Y}_{t-j}++\pi_{2} \mathrm{RE}_{t-j}+\pi_{3} \mathrm{TOR}_{t-j}+\pi_{4} \mathrm{FDI}_{t-j}+\pi_{5} \mathrm{CO}_{2} \mathrm{e}_{t-j}+\vartheta \mathrm{ECT}_{t-j} \\
+ & \beth_{t} \ldots \\
& \ldots \mathrm{TOR}_{t}= \\
& \tau_{0}+\sum_{b=1}^{p} \tau_{1} \Delta \mathrm{TOR}_{t-b}+\sum_{b=1}^{p} \tau_{2} \Delta \mathrm{Y}_{t-b}+\sum_{b=1}^{p} \tau_{3} \Delta \mathrm{RE}_{t-b}+\sum_{b=1}^{p} \tau_{4} \Delta \mathrm{CO}_{2} \mathrm{e}_{t-b}+\sum_{b=1}^{p} \tau_{5} \Delta \mathrm{FDI}_{t-b} \\
& +\sum_{b=1}^{p} \tau_{6} \Delta \mathrm{D}_{t-b}+\pi_{1} \mathrm{Y}_{t-j}+\pi_{2} \mathrm{RE}_{t-j}+\pi_{3} \mathrm{TOR}_{t-j}+\pi_{4} \mathrm{FDI}_{t-j}+\pi_{5} \mathrm{CO}_{2} \mathrm{e}_{t-j}+\vartheta \mathrm{ECT}_{t-j} \\
& +\mathrm{I}_{t} \ldots \\
& +\sum_{b=1}^{p} \tau_{6} \Delta \mathrm{D}_{t-b}+\pi_{1} \mathrm{FDI}_{t-j}+\pi_{2} \mathrm{TOR}_{t-j}+\pi_{3} \mathrm{Y}_{t-j}+\pi_{4} \mathrm{CO}_{2} \mathrm{e}_{t-j}+\pi_{5} \mathrm{RE}_{t-j}+\vartheta \mathrm{ECT}_{t-j} \\
+ & \sum_{b=1} \tau_{6} \Delta \mathrm{D}_{t-b}+\pi_{1} \mathrm{RE}_{t-j}+\pi_{2} \mathrm{Y}_{t-j}+\pi_{3} \mathrm{TOR}_{t-j}+\pi_{4} \mathrm{CO}_{2} \mathrm{e}_{t-j}+\pi_{5} \Delta \mathrm{TOR}_{t-l}+\vartheta \mathrm{ECT}_{t-j} \\
\Delta \mathrm{RE}_{t}= & +\sum_{b=1}^{p} \tau_{1} \Delta \mathrm{RE}_{t-b}+\sum_{b=1}^{p} \tau_{2} \Delta \mathrm{Y}_{t-b}+\sum_{b=1}^{p} \tau_{3} \Delta \mathrm{TOR}_{t-b}+\sum_{b=1}^{p} \tau_{4} \Delta \mathrm{CO}_{2} \mathrm{e}_{t-b}+\sum_{b=1}^{p} \tau_{5} \Delta \mathrm{FDI}_{t-b} \\
+ &
\end{aligned}
$$

where $\mathrm{CO}_{2} \mathrm{e}, \mathrm{Y}, \mathrm{TOR}, \mathrm{RE}$ andFDI are the variables considered in the current study, and $\mathrm{D}$ and $\Delta$ are a dummy to capture the breaks and differenced operator of the regression equations. $\beth_{t}$ Indicates the uncorrelated and normally distributed error term of the equations (6-10). These particular equations are the error correction models (ECM) with no restricted (conditional ECM) coefficients (Pesaran et al. 2001). In the equations, 6-10 contains summation operators which are short-run dynamics, and the rest of the parts of equations are long-run relationships (Shahbaz et al. 2013). Before estimation, the equation, the lags of the whole system of equations, would be selected using one of the criteria, including AIC, BIC, or SIC. Referring to the baseline equations above, we have formulated the null and alternative of the hypothesis of the bound test are as under; 
Null: No cointegration.

Alternative: Cointegration.

Using the bound test approach for lagged level variables, the null hypothesis of cointegration is;

$$
\begin{aligned}
& H_{0}=\pi_{1}=\pi_{2}=\pi_{3}=\pi_{4}=\pi_{5}=0 \\
& H_{a}=\pi_{1} \neq \pi_{2} \neq \pi_{3} \neq \pi_{4} \neq \pi_{5} \neq 0
\end{aligned}
$$

The distribution of these statistics is nonstandard; therefore, its critical values are not available for the mixture of I(1) and I(0). Therefore Pesaran et al. (2001) developed critical values based on the asymptotic distribution of the F-test. This provides upper and lower values of bonds for a number of variables. In ARDL bound testing approach, lower bound considers all the variables are $\mathrm{I}(0)$, and upper bound assumes that all the variables are $\mathrm{I}(1)$, and there are no values for I(2) order and is the limitation of this test. When the F-statistics falls below $\mathrm{I}(0)$, we reject the null hypothesis, and there is no cointegration. On the other hand, if the F-statistics falls above the I(1) bound limit, the conclusion is cointegration. If the F-test values fall between $\mathrm{I}(0)$ and $\mathrm{I}(1)$ bands, the results considered inconclusive. In that case, we have to test other methods of cointegration.

While creating the short-run relationship, it is possible to have hidden cointegration, which fails to provide an accurate interpretation of estimated non-symmetric coefficients. In that case, a restriction may be imposed on the regression equations (Granger and Yoon 2002). Hence, to see the log-run dynamics, we estimate the error correction model. Where $\vartheta$ is the estimator of error correction (ECT) of the short-run models. The significant negative value of ECT $(-1)$ is expected, which indicates the adjustment speed after a shocking interval to its long-run equilibrium state.

\subsubsection{Unit roots}

ARDL approach does not force to diagnose the integration order between variables but to analyze the series for higher than the integration of $\mathrm{I}(1)$, which possibly provides inconsistent results, and F statistics from the test go null and void (Ahmad et al. 2018). Therefore, before testing the variables for long-run dynamics, it is compulsory to examine the series for stationarity. It is a problem of time series variables that they move in a significant relationship by making trends and shapes concludes in spurious regressions (Granger and Newbold 1974; Hossain 2012; Khan et al. 2020). To check their level of integration, we used two frequently used tests of unit roots in the current study; the first is $\mathrm{Ng}$ and Perron (2001), which incorporates the Dickey fuller's GLS and Philip Perron test. Ng and Perron (2001) claim that this test of unit root performs well as compared to other conventional tests of unit roots (ADF and PP), especially in case of negative moving averages and small sample sizes (Malik and Atiq-ur-Rehman 2015; Seker et al. 2015). This test works on four tests statistics, "MZa, MZt, MSB and MPT, the null hypothesis of the series which have unit root can be rejected if the calculated values of MZa and MZt (MZa, MZt $>$ Critical values at 5\%) are higher than the critical values at 5\% and calculated statistics of MSB and MPT (MSB, MPT < critical values at 5\%) are less than critical values at 5\% level" (Seker et al. 2015).

The second test of unit root used in the current study is Zivot and Andrews (1992) test to capture if any breaks in the data. Before applying the cointegration methods with asymmetry and breaks, it is needed to detect if there are structural shifts in regimes. Therefore, 
we tested the series for unit roots with structural breaks in this study. After examining the variables for stationarity, we further checked the variables for joint long-run relationships. We tested them for mutual long run bonding with the help of ARDL bound testing methodology (Pesaran et al. 2001; Shin et al. 2014). The required test uses the conventional Wald test statistics, which shows that the long-run coefficients $\pi_{1}=\pi_{2}=\pi_{3}=\pi_{4}=\pi_{5}$ are all simultaneously equal to zero. Where alternative uses in this test indicate that $\pi_{1} \neq \pi_{2} \neq \pi_{3} \neq \pi_{4} \neq \pi_{5}$ not equal to zero.

\subsubsection{Hatemi-J cointegration}

To counter verify the long-run relationship, we then tested the Hatemi-J (2008) test of cointegration with unknown breaks in the current study. It is the drawback of other cointegration methods Johansen (1988) and Pesaran et al. (2001) that they assume the cointegration vector remains stable and there are no shifts in the regimes in the study period. However, in dynamic economy breaks in data series may occur due to changing behaviours of economic actors and affect the economy at large (Seker et al. 2015). In that case, these breaks in the data can lead the economy with misleading decisions. To rectify this issue, Hatemi-J (2008) developed a test for time series with unknown shifts in regime by developing three residual-based tests (ADF, Zt, and $\mathrm{Za}$ ). These tests are designed to identify the breakpoints in data endogenously, and Monte Carlo simulations suggested that these tests have high power and small distortions. If the calculated values of these tests are higher than critical values at $5 \%$ or below, the result is cointegration in the data (Seker et al. 2015). After reviewing the order of integration and cointegration vectors, we established the longrun relationship of Eq. (6) by using the NARDL approach.

\subsubsection{VECM granger causality}

The causal relationship found to be very important while making policy tools in the empirical analysis. Therefore understanding the importance of causal inferences and nature of the current study, we tested the variables for causality based vector error correction model among the variables in our study. We estimated the first lag of ECT to explore the long-run dynamics of the chosen variables. The equations (xi-xv) given below are the augmented form of Granger causality based on the VECM approach.

$\left[\begin{array}{c}\Delta \mathrm{COe}_{2, t} \\ \Delta \mathrm{Y}_{t} \\ \Delta \mathrm{TOR}_{t} \\ \Delta \mathrm{RE}_{t} \\ \Delta \mathrm{FDI}_{t}\end{array}\right]=\left[\begin{array}{c}K_{1} \\ K_{2} \\ K_{3} \\ K_{4} \\ K_{5}\end{array}\right]+\sum_{K=1}^{p}\left[\begin{array}{ccccc}\alpha_{11} & \alpha_{12} & \alpha_{13} & \alpha_{14} & \alpha_{15} \\ \alpha_{21} & \alpha_{22} & \alpha_{23} & \alpha_{24} & \alpha_{25} \\ \alpha_{31} & \alpha_{32} & \alpha_{33} & \alpha_{34} & \alpha_{35} \\ \alpha_{41} & \alpha_{42} & \alpha_{43} & \alpha_{44} & \alpha_{45} \\ \alpha_{51} & \alpha_{52} & \alpha_{53} & \alpha_{54} & \alpha_{55}\end{array}\right]\left[\begin{array}{c}\Delta \mathrm{COe}_{2, t-k} \\ \Delta \mathrm{Y}_{t-k} \\ \Delta \mathrm{TOR}_{t-k} \\ \Delta \mathrm{RE}_{t-k} \\ \Delta \mathrm{FDI}_{t-k}\end{array}\right]+\left[\begin{array}{c}\theta_{1} \\ \theta_{2} \\ \theta_{3} \\ \theta_{4} \\ \theta_{5}\end{array}\right] \mathrm{ECT}_{t-1}+\left[\begin{array}{c}\mu_{1} \\ \mu_{2} \\ \mu_{3} \\ \mu_{4} \\ \mu_{5}\end{array}\right] \ldots$

where $\Delta$ is used for the differenced operator, $K_{1,2,3,4 \text { and } 5}$ are the constants of the regression equations, $\theta_{1,2,3,4 \text {,and5 }}$ are the coefficients of error correction term (ECT). Its numerical value is expected to be negative. $\mu_{1,2,3,4 \text { and } 5}$ are the error terms, and $\alpha_{1,1}$ to $\alpha_{5,5}$ are the parameters that need to be estimated, which will demonstrate the short-run causality across the variables. Finally, the dummies are taken exogenous in the VECM Granger causality; therefore, they are eliminated from the VECM equation (11) simultaneously. 
Table 2 Unit root test (Ng and Perron)

\begin{tabular}{|c|c|c|c|c|c|c|}
\hline \multicolumn{2}{|c|}{ Variable (s) } & \multirow{2}{*}{$\begin{array}{l}\mathrm{MZ}_{\alpha} \\
-0.33252\end{array}$} & \multirow{2}{*}{$\frac{\mathrm{MZ}_{t}}{-0.24787}$} & \multirow{2}{*}{$\frac{M S B}{0.74543}$} & \multirow{2}{*}{$\begin{array}{l}\text { MPT } \\
31.4831\end{array}$} & \multirow[t]{2}{*}{ Order } \\
\hline $\mathrm{CO}_{2} \mathrm{e}$ & At level & & & & & \\
\hline & At first-diff & -12.5924 & -2.50871 & 0.19922 & 1.94757 & $\mathrm{I}(1)$ \\
\hline \multirow[t]{2}{*}{ TOR } & At level & -0.24526 & -0.14437 & 0.58865 & 22.5741 & \\
\hline & At first-diff & -12.4824 & -2.49484 & 0.19987 & 1.97574 & \\
\hline \multirow[t]{2}{*}{ Y } & At level & -1.43573 & -0.60496 & 0.42136 & 12.0085 & $\mathrm{I}(1)$ \\
\hline & At first-diff & -11.854 & -1.90708 & 0.16088 & 3.87271 & \\
\hline \multirow[t]{2}{*}{ FDI } & At level & -14.6622 & -2.70727 & 0.18464 & 1.67218 & $\mathrm{I}(0)$ \\
\hline & At first-diff & -11.3358 & -2.3807 & 0.21002 & 2.16145 & \\
\hline \multirow[t]{5}{*}{ RE } & At level & -0.18096 & -0.13688 & 0.75639 & 33.3865 & $\mathrm{I}(1)$ \\
\hline & At first-diff & -12.7632 & -2.52435 & 0.19778 & 1.9266 & \\
\hline & Critical-values at $1 \%$ & -13.8 & -2.58 & 0.174 & 1.78 & \\
\hline & Critical-values at $5 \%$ & -8.1 & -1.98 & 0.233 & 3.17 & \\
\hline & Critical-values at $10 \%$ & -5.7 & -1.62 & 0.275 & 4.45 & \\
\hline
\end{tabular}

Table 3 Zivot and Andrews Test of unit root

\begin{tabular}{lllll}
\hline Variable(s) & Stationarity & T-test & Breaks & Order \\
\hline $\mathrm{CO}_{2} \mathrm{e}$ & Level & -2.45 & 2011 & $\mathrm{I}(1)$ \\
& 1st Diff & -7.715 & 2008 & \\
TOR & Level & -4.742 & 2006 & $\mathrm{I}(1)$ \\
& 1st Diff & -6.806 & 2004 & \\
$\mathrm{Y}$ & Level & -3.667 & 2005 & $\mathrm{I}(1)$ \\
& 1st Diff & -5.405 & 2004 & \\
FDI & Level & -4.15 & 2004 & $\mathrm{I}(1)$ \\
& 1st Diff & -4.82 & 2008 & \\
RE & Level & -2.497 & 2010 & $\mathrm{I}(1)$ \\
& 1st Diff & -7.131 & 2003 & \\
\hline
\end{tabular}

Critical values at $1 \%, 5 \%$ and $10 \%$ are $-5.34,-4.80$ and -4.58

\section{Results and discussion}

The benefit of using the Pesaran ARDL model in the empirical analysis is that it does not require pretesting of unit roots across the variables, however, to identify if any variable is of a higher order than I(1), we examined the stationary level across the variables. $\mathrm{Ng}$ and Perron (2001) results presented in Table 2 explores that no variable is of higher integration level than I(1) however, FDI is found to be stationary at level (MZa and MZt $>$ critical values, and MSB and MPT < critical values at 5\%) and other variables $\left(\mathrm{CO}_{2} \mathrm{e}, \mathrm{Y}, \mathrm{TOR}\right.$, and RE) turned stationary after converting to the first difference.

Unit roots with structural breaks (Zivot-Andrews) are given in Table 3. The outcomes from this test imply that the chosen variables are non-stationary at the level and stationary after taking the first difference. The results of both tests of unit roots have declared that in levels, they are non-stationarity, and at the first difference and repeating the process explores the stationary properties. Therefore, it is imperative to test the time series variables for the long-run equilibrium relationship. 
After analyzing the data for stationary order and found that the variables $\left(\mathrm{CO}_{2} \mathrm{e}, \mathrm{TOR}\right.$, Income RE, and FDI) have a unique order of integration. We further determined the series for long-run cointegration by introducing the dummy variables into each model. The results of the bound test presented in Table 4 clarify that the calculated $\mathrm{F}$ statistics is higher than critical values at $1 \%$ level in all the models except model 2, which is significant at 5\% level; therefore, bound test results conclude that the chosen variables have a cointegration association. For example, in ARDL, F-statistics for the $\mathrm{CO}_{2} \mathrm{e}$ model is 6.88 , that is greater than the upper bound limit at $1 \%$, suggesting that the variables have long-term linkages. Similarly, for the income model, the value of the F-test is 3.147 that is higher than the upper bound limit at a 5\% level, which indicates the cointegration relationship. In the case of the Tourism index, its value is 6.095; for FDI, it is 5.363, and finally, for the renewable energy model, the value of the F-test is 5.197. All the test statistics are higher than critical values at a $1 \%$ level. Therefore, the results indicate the existence of an equilibrium relationship between the variables for all five models.

Since we have introduced the dummy variables in the ARDL model to detect the shocks in the data based on the Zivot-Andrews unit root test to identify the given period of shock; however, to make the results robust, we counter verified the outcomes by using Hatemi$\mathbf{J}$ (2008) test of cointegration with unknown endogenous breaks and results are given in Table 5. These tests also specified identical results for the current study by inferring that $\mathrm{ADF}, \mathrm{Z}_{\mathrm{a}}$, and $\mathrm{Z}_{\mathrm{t}}$ values are higher in absolute terms than critical values at $5 \%$ or below, which confirms the cointegration relationship between the considered variables for all models.

The long-run estimates are given in Table 6. The results for model $1\left(\mathrm{CO}_{2} \mathrm{e}\right)$ show that income has a significant positive relationship with $\mathrm{CO}_{2} \mathrm{e}$ emission for Pakistan, where a one per cent increase in income increases the $\mathrm{CO}_{2} \mathrm{e}$ with $0.524 \%$. These results are consistent with the past studies of (Adebola Solarin et al. 2017; Apergis et al. 2017; Caron and Fally 2018; Destek and Sarkodie 2019; Dogan et al. 2017). The nexus of tourism and $\mathrm{CO}_{2}$ e has exposed a positive significant (0.016) relationship. This relationship, in the case of Pakistan, implies that an upsurge in net tourism is degrading the natural environment. The study results are referring to the outcomes of Katircioglu et al. (2014); Lei and Jing (2016); Lee and Brahmasrene (2013); and Zhang and Liu (2019) who specified that the increase in international tourist inflows has increased environmental degradation in terms of $\mathrm{CO}_{2}$ emission through travel and transport and depleting the natural resources for recreational purposes, whereas the long-run increase in FDI has accelerated the $\mathrm{CO}_{2} \mathrm{e}$ with $0.032 \%$. Therefore, our results conclude with the presence of the "pollution haven hypothesis" (PHH). The results are similar to existing findings of Abdouli and Hammami (2018); Gorus and Aslan (2019); Khan et al. (2019); Naz et al. (2019), and Sapkota and Bastola (2017); who narrated that FDI's to respective regions have further intensified the $\mathrm{CO}_{2} \mathrm{e}$. However, the impact of renewable energy is helping to combat $\mathrm{CO}_{2} \mathrm{e}$ in Pakistan. The investments in clean and renewable energy sources help to eradicate the impurities in the environment; therefore, renewable energy mitigates $\mathrm{CO}_{2}$ in the environment (Bekhet and Othman 2018; Dogan and Ozturk 2017; Bilgili et al. 2016).

The results of Model $2(\mathrm{Y})$ for income indicate that there is a positive relationship between $\mathrm{CO}_{2} \mathrm{e}$ and income; the empirical results support the findings of Chaabouni and Saidi (2017); Obradović and Lojanica (2017) who found that increase in $\mathrm{CO}_{2} \mathrm{e}$ has a causal relationship with income. Similarly, tourism-led growth hypothesis is also true in case of Pakistan, this states that a one per cent increase in tourism upsurges income with $0.030 \%$ in the long run, referring to the studies of Ridderstaat et al. (2014), and Tang and Tan (2013). Moreover, the inflows of foreign direct investment into Pakistan also improves the growth 


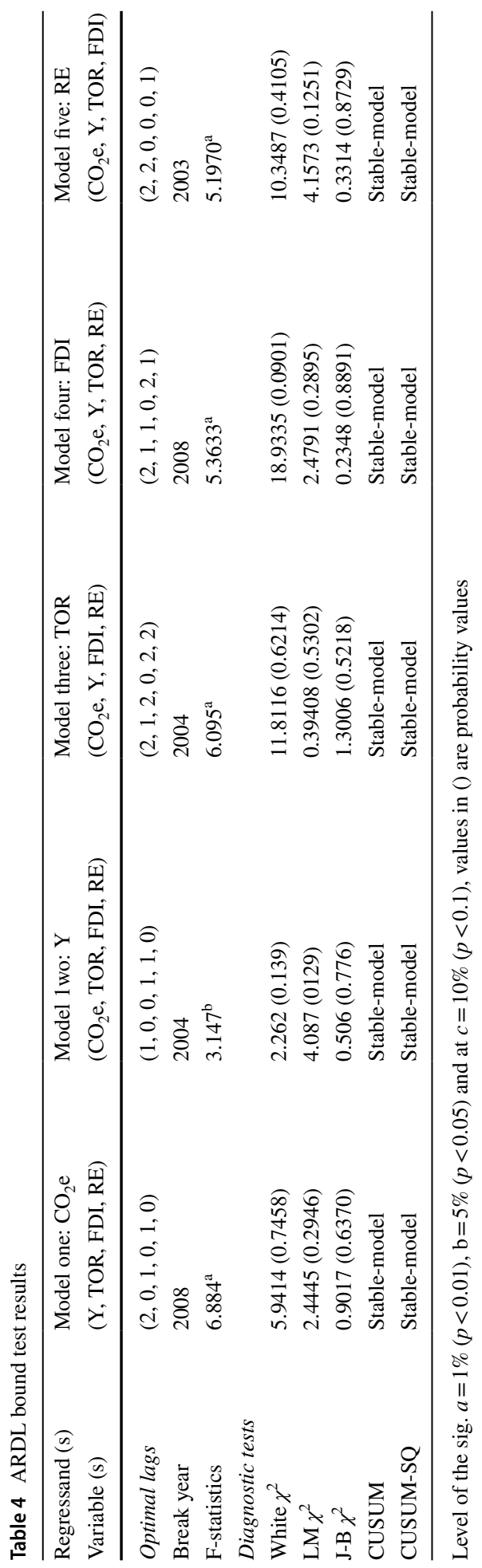


Table 5 Cointegration (Hatemi J) test with shifts in regime

\begin{tabular}{llll}
\hline Model (s) & ADF & $Z_{t}$ & $Z_{a}$ \\
\hline $\mathrm{CO}_{2} \mathrm{e} / \mathrm{Y}, \mathrm{TOR}, \mathrm{FDI}, \mathrm{RE}$ & -21.051 & -7.866 & -139.076 \\
$\mathrm{Y} / \mathrm{CO}_{2} \mathrm{e}, \mathrm{TOR}, \mathrm{FDI}, \mathrm{RE}$ & -14.55 & -6.738 & -134.171 \\
$\mathrm{TOR} / \mathrm{CO}_{2} \mathrm{e}, \mathrm{Y}, \mathrm{FDI}, \mathrm{RE}$ & -9.176 & -8.058 & -139.602 \\
$\mathrm{RE} / \mathrm{CO}_{2} \mathrm{e}, \mathrm{Y}, \mathrm{TOR}, \mathrm{FDI}$ & -10.111 & -8.602 & -141.716 \\
$\mathrm{FDI} / \mathrm{CO}_{2} \mathrm{e}, \mathrm{Y}, \mathrm{TOR}, \mathrm{RE}$ & -8.1 & -5.632 & -130.288 \\
\hline
\end{tabular}

Critical values at $1 \%$ and $5 \%$ for $\mathrm{ADF}$ and $Z_{t}$ are $-8.353,-7.705$; and $Z_{a}$ are -140.135 and -123.87 respectively

of the country. Thus they are beneficial to boost up the economy of the country. These results support the findings of past studies (Hakimi and Hamdi 2016).

The results of Model 3 (TOR) imply that the relationship between $\mathrm{CO}_{2} \mathrm{e}$ and TOR is negative, which indicates a one per cent increase in $\mathrm{CO}_{2} \mathrm{e}$ decreases the TOR with $-1.243 \%$ in the long run. The impact of environmental degradation based on $\mathrm{CO}_{2} \mathrm{e}$ is vast in Pakistan. The tourists who are travelling to Pakistan are conscious regarding environmental quality. The coefficient of income is 0.303 and significant; this explains that an increase in income improves the tourist places and thus enhances the tourism sector in the country. This finding supports the existing pieces of evidence of Payne and Mervar (2010), and Tang (2011), who claimed that upsurge in income is beneficial to the tourism sector across the regions in their respective studies. FDI is contributing negatively to the tourism sector. This may be because the reason that FDI in the country mainly focused on the dirty technology imports, thus increasing pollutants to the environment that discourages tourist flows. On the other hand, renewable energy is a source to escalate the tourism industry in Pakistan.

When we explore Model 4 (FDI), the results revealed that there is a significant positive direct relationship between $\mathrm{CO}_{2} \mathrm{e}$ and FDI. This relationship indicates the existence of a bidirectional long-run relationship between FDI and $\mathrm{CO}_{2} \mathrm{e}$ in the case of Pakistan. Similarly, the relationship between income and FDI is also significant, which reveals that the increase in income provides opportunities to outsiders to invest in Pakistan; this attracts the FDI inflows to the country. On the other hand, there is a negative relationship between TOR and inflows, which indicates that a one per cent increase in tourism index to Pakistan declines the FDI with -0.298 . In contrast, the contribution of renewable energy use to FDI is also significant and positive.

Finally, turning to the Model 5 (renewable energy); the results explored the negative and significant relationship with $\mathrm{CO}_{2} \mathrm{e}$; the rate of negative relationship is $-0.782 \%$ in the long run. The contribution of RE to economic growth is encouraging and have positive, beneficial impacts. Thus, it declares that a one per cent increase in income helps to increase renewable energy with $0.559 \%$ in the long run. There is a need to reassure the investors to invest in renewable energy sources, thus accelerating economic growth with any cost to the environment. Tourism is highly acceptable in the case of renewable energy consumption; it implies that a one per cent increase in tourism improves the RE with $0.038 \%$ in the long run.

\subsection{Granger causality in the VECM framework}

The VECM Granger-causality test is adopted to determine the causal links between the selected variables. The results summarized in Table 7 explore several causal directions, which 


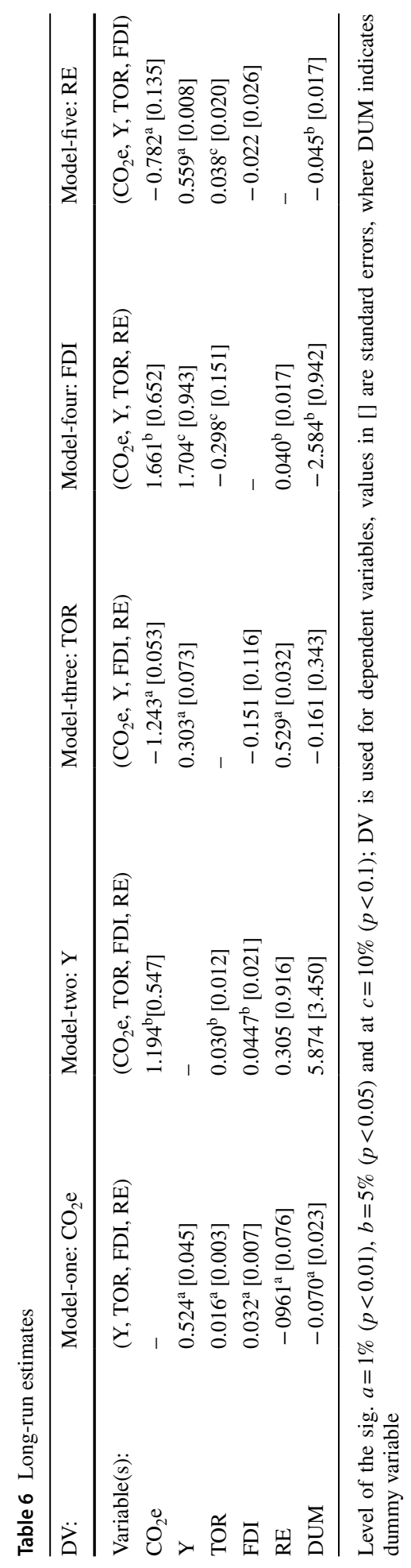


Table 7 VECM Granger-causality results

\begin{tabular}{|c|c|c|c|c|c|c|}
\hline \multirow[t]{2}{*}{ Variable(s) } & \multicolumn{5}{|c|}{ Chi-square $\left(\chi^{2}\right)$ values of short-run causal results } & \multirow{2}{*}{$\begin{array}{l}\text { Long run } \\
\text { causal results } \\
\text { ECT }(-1)\end{array}$} \\
\hline & $\mathrm{CO}_{2} \mathrm{e}$ & Y & TOR & FDI & $\mathrm{RE}$ & \\
\hline $\mathrm{CO}_{2} \mathrm{e}$ & - & $0.204(0.903)$ & $8.690^{\mathrm{b}}(0.013)$ & $2.213(0.330)$ & $0.059(0.970)$ & $\begin{array}{r}-0.333^{\mathrm{b}} \\
(0.030)\end{array}$ \\
\hline Y & $0.948(0.624)$ & - & $3.598^{\mathrm{c}}(0.065)$ & $0.883(0.643)$ & $1.655(0.437)$ & $\begin{array}{r}-0.493^{\mathrm{b}} \\
(0.012)\end{array}$ \\
\hline TOR & $1.674(0.432)$ & $8.461^{\mathrm{b}}(0.014)$ & - & $0.063(0.968)$ & $3.002(0.222)$ & $\begin{array}{r}-0.688^{\mathrm{a}} \\
(0.002)\end{array}$ \\
\hline FDI & $0.946(0.623)$ & $9.757^{\mathrm{a}}(0.007)$ & $7.253^{\mathrm{b}}(0.026)$ & - & $2.228(0.328)$ & $\begin{array}{r}-2.551^{\mathrm{a}} \\
(0.004)\end{array}$ \\
\hline RE & $1.688(0.429)$ & $5.369^{\mathrm{c}}(0.068)$ & $6.454^{\mathrm{b}}(0.039)$ & $1.153(0.568)$ & - & $\begin{array}{r}-0.128^{\mathrm{a}} \\
(0.009)\end{array}$ \\
\hline
\end{tabular}

Level of the sig. $a=1 \%(p<0.01), b=5 \%(p<0.05)$ and at $c=10 \%(p<0.1)$; values in () are probability values

are the foundation to deliberate the policy guidelines for the current study. The results indicate the existence of two-way causality between tourism index and income in the short run. Referring to previous studies Ridderstaat et al. (2014), and Tang and Tan (2013), who inferred that increase in tourism development, in turn, improve the economic growth of the countries through various channels for example; foreign exchange earnings, employment, business establishments, infrastructure development, government revenues, and different multipliers effects. On the other hand, we found unidirectional causality between the tourism index and renewable energy consumption. Our results indicate that the tourism index has a significant effect on the short- and long-term simultaneous use of renewable energy. Moreover, our findings explored unidirectional causality from FDI to tourism, unlike the conventional scenario (Ben Jebli et al. 2019; Siddiqui and Siddiqui 2019), who revealed that FDI unidirectional causes tourism. The causal results also indicate $\mathrm{CO}_{2} \mathrm{e}$ causes tourism; FDI and renewable energy simultaneously causing income in Pakistan. Finally, for all models, the ECT $(-1)$ value is negative and significant, thus suggesting the presence of a long-run causal relationship between the variables selected.

Before drawing the inferences based on the results of these models, we tested all the models (1-5) for any econometric issues in error terms, including Heteroscedasticity, Autocorrelation, and normality. The insignificant outcomes (given at the bottom of Table 4) of the Breusch-Godfrey LM test (LM $\chi^{2}$ ), White heteroscedasticity (White $\chi^{2}$ ), and Jarque-Bera test $\left(\mathrm{J}-\mathrm{B} \chi^{2}\right)$ have confirmed that the errors of the models are free of any econometric issue. The stability of estimators is analyzed through CUSUM and CUSUM squares (fig. A2-A6 in appendix), which confirms the estimators are stable at a 5\% level for both CUSUM and the CUSUM sum of squares graphs. The results, therefore, are reasonable for further prediction and policy guidance. 


\section{Conclusion and policy guidelines}

The study is conducted on to explore the dynamic linkages between $\mathrm{CO}_{2} \mathrm{e}$, tourism indicators, income, renewable energy, and foreign direct investment over 1990-2017 for Pakistan using an ADRL approach. Before applying ARDL, the variables are examined for stationarity using first and second-generation unit root tests. The cointegrating relationships obtained from bound and Hatemi-J cointegration tests have determined that the variables have long-run equilibrium relationships both in linear and in the presence of structural breaks. In the next section, the dummy variable is introduced in the ARDL framework to account for the possible effects of structural breaks in the data to explore the long-run dynamics of the variables; besides it, we applied VECM based Granger causality to analyze the data for causal linkages.

This study's empirical results are unique and support three out of four developed hypotheses by using long-run estimation by incorporating regime shifts and causality results. First, the growth driven by tourism and the tourism hypothesis driven by economic growth are confirmed, which means that the rise in tourism improves the economic indicators (GDP); similarly, the improvements in economic growth increase the tourism industry of the country by investing on enhancing the tourism destinations, hoteling, infrastructures, and transportation facilities. Secondly, Tourism found to be a significant contributor of $\mathrm{CO}_{2} \mathrm{e}$ in Pakistan, which validates the second hypothesis. Renewable energy and tourism have a direct and positive relationship, which postulates that the increase in energy based on renewable resources is escalating Pakistan's tourism industry (hypothesis-3). Finally, the VECM Granger causality revealed that there is unidirectional causality flowing from FDI to tourism. Besides these results, the long-run estimates provide evidence that FDI and RE have reliable impacts on both environment and economic growth in the country.

The study has revealed some specific policies in the domain of sustainable tourism, renewable energy and sustainable economic growth process. Empirical outcomes of the current research have allowed us to provide policy insights to policymakers in Pakistan. The results revealed that tourism improves economic growth and contributes to $\mathrm{CO}_{2} \mathrm{e}$ in Pakistan. It is not plausible to reduce the pace of growth; however, there is a need for public awareness regarding environmental commodities, eco-friendly, smart, and sustainable tourism policies. Similarly, the local bodies should be in diminishing emission frequencies by promoting green tourism. Both FDI and tourism are contributing to $\mathrm{CO}_{2} \mathrm{e}$ emissions; restrictive measures of FDI inflows to Pakistan are not desirable due to its significant growth need. Therefore the focus is strongly needed to adopt the green FDI inflows along with investment in energy efficiency and environmentally friendly technologies to stimulate the sustainable pace of economic development. Further, if this FDI is planned through green investment can improve the environmental quality and sustainable tourism sector in Pakistan. The investment in renewable energy sources is desirable because it is improving economic growth, reducing $\mathrm{CO}_{2} \mathrm{e}$ by fostering tourism demand in the country. Thus, the investment through FDI is encouraged in clean technologies; therefore, to improve the environment, tourism, and growth at the same time. The provision of government budget in green infrastructure is of utmost need; it will not only support sustainable tourism but also reduce the negative environmental impacts of the urbanization process.

Regardless of the efficient estimates, there is still a vacuum for future research based on more indicators of tourism. For example, the extended period is taken by adding exchange rates (fluctuations in exchange rates in countries like Pakistan have responsible impacts on economic growth) to conduct a new study to provide new insights. Extended time-series 
studies in the dimension of the environment and tourism are also required by adding renewable and non-renewable energy consumption indicators for comparison in the models. One more significant direction for the studies on tourism is the impact of novel COVID-19. Tourism is one of the leading sectors of the economy, which has been abruptly affected by novel COVID-19. Since, in fear of the virus, every country has banned tourist inbound; therefore, tourism-based economies are feeling problems in such domain. However, due to limitation of such data, this study has limited its circle to 1990-2017 for formal analysis; however, future studies must consider this point to produce timely policies for tourism development. Finally, similar studies are also conducted in a panel of countries, thus to make strong spatial policies on sustainable tourism worldwide.

\section{References}

Abdouli, M., \& Hammami, S. (2018). Economic growth, environment, FDI inflows, and financial development in middle east countries: Fresh evidence from simultaneous equation models. Journal of the Knowledge Economy. https://doi.org/10.1007/s13132-018-0546-9.

Adebola Solarin, S., Al-Mulali, U., \& Ozturk, I. (2017). Validating the environmental Kuznets curve hypothesis in India and China: The role of hydroelectricity consumption. Renewable and Sustainable Energy Reviews, 80, 1578-1587. https://doi.org/10.1016/J.RSER.2017.07.028.

Adnan Hye, Q. M., \& Ali Khan, R. E. (2013). Tourism-led growth hypothesis: A case study of Pakistan. Asia Pacific Journal of Tourism Research, 18(4), 303-313. https://doi.org/10.1080/10941665.2012.658412.

Ahmad, M., Khan, Z., Ur Rahman, Z., \& Khan, S. (2018). Does financial development asymmetrically affect $\mathrm{CO}_{2}$ emissions in China? An application of the nonlinear autoregressive distributed lag (NARDL) model. Carbon Management, 9(6), 631-644. https://doi.org/10.1080/17583004.2018.1529998.

Ahmad, M., Khattak, S. I., Khan, A., \& Rahman, Z. U. (2020). Innovation, foreign direct investment (FDI), and the energy-pollution-growth nexus in OECD region: A simultaneous equation modeling approach. Environmental and Ecological Statistics. https://doi.org/10.1007/s10651-020-00442-8.

Alam, A., Malik, O. M., Ahmed, M., \& Gaadar, K. (2015). Empirical analysis of tourism as a tool to increase foreign direct investment in developing country: Evidence from Malaysia. Mediterranean Journal of Social Sciences, 6(4S3), 201-206. https://doi.org/10.5901/mjss.2015.v6n4s3p201.

Apergis, N., Christou, C., \& Gupta, R. (2017). Are there Environmental Kuznets curves for US state-level $\mathrm{CO}_{2}$ emissions? Renewable and Sustainable Energy Reviews, 69, 551-558. https://doi.org/10.1016/j. rser.2016.11.219.

Apergis, N., \& Payne, J. E. (2012). Tourism and growth in the Caribbean-Evidence from a panel error correction Model. Tourism Economics, 18(2), 449-456. https://doi.org/10.5367/te.2012.0119.

Balaguer, J., \& Cantavella-Jordá, M. (2002). Tourism as a long-run economic growth factor: The Spanish case. Applied Economics, 34(7), 877-884. https://doi.org/10.1080/00036840110058923.

Bekhet, H. A., \& Othman, N. S. (2018). The role of renewable energy to validate dynamic interaction between $\mathrm{CO}_{2}$ emissions and GDP toward sustainable development in Malaysia. Energy Economics, 72, 47-61. https://doi.org/10.1016/J.ENECO.2018.03.028.

Ben Jebli, M., Ben Youssef, S., \& Apergis, N. (2015). The dynamic interaction between combustible renewables and waste consumption and international tourism: The case of Tunisia. Environmental Science and Pollution Research, 66, 12050-12061. https://doi.org/10.1007/s11356-015-4483-X.

Ben Jebli, M., Ben Youssef, S., \& Apergis, N. (2019). The dynamic linkage between renewable energy, tourism, $\mathrm{CO}_{2}$ emissions, economic growth, foreign direct investment, and trade. Latin American Economic Review, 28(1), 2. https://doi.org/10.1186/s40503-019-0063-7.

Bhuiyan, M. A., Jabeen, M., Zaman, K., Khan, A., Ahmad, J., \& Hishan, S. S. (2018). The impact of climate change and energy resources on biodiversity loss: Evidence from a panel of selected Asian countries. Renewable Energy, 117, 324-340. https://doi.org/10.1016/J.RENENE.2017.10.054.

Bilgili, F., Koçak, E., \& Bulut, Ü. (2016). The dynamic impact of renewable energy consumption on $\mathrm{CO}_{2}$ emissions: A revisited environmental Kuznets curve approach. Renewable and Sustainable Energy Reviews, 54, 838-845. https://doi.org/10.1016/J.RSER.2015.10.080.

Caron, J., \& Fally, T. (2018). Per capita income, consumption patterns, and $\mathrm{co}_{2}$ emissions (No. 24923). Cambridge, MA. Doi:https://doi.org/10.3386/w24923. 
Chaabouni, S., \& Saidi, K. (2017). The dynamic links between carbon dioxide $\left(\mathrm{CO}_{2}\right)$ emissions, health spending and GDP growth: A case study for 51 countries. Environmental Research, 158, 137-144. https://doi.org/10.1016/j.envres.2017.05.041.

Claudio, Q., P. M. M. \& R. M. (2010). Sustainable tourism indicators: a mapping of the Italian Destinations. http://www.economia.uniparthenope.it/Siti_docenti\%0A/cquintano/pubblicazioni/Tourism/Indic ators.pdf.

Del Pablo-Romero, P. M., \& Molina, J. A. (2013). Tourism and economic growth: A review of empirical literature. Tourism Management Perspectives. https://doi.org/10.1016/j.tmp.2013.05.006.

Destek, M. A., \& Sarkodie, S. A. (2019). Investigation of environmental Kuznets curve for ecological footprint: The role of energy and financial development. Science of The Total Environment, 650(Pt 2), 2483-2489. https://doi.org/10.1016/j.scitotenv.2018.10.017.

Dogan, E., \& Ozturk, I. (2017). The influence of renewable and non-renewable energy consumption and real income on $\mathrm{CO}_{2}$ emissions in the USA: Evidence from structural break tests. Environmental Science and Pollution Research, 24(11), 10846-10854. https://doi.org/10.1007/s11356-017-8786-y.

Dogan, E., Seker, F., \& Bulbul, S. (2017). Investigating the impacts of energy consumption, real GDP, tourism and trade on $\mathrm{CO}_{2}$ emissions by accounting for cross-sectional dependence: A panel study of OECD countries. Current Issues in Tourism, 20(16), 1701-1719. https://doi.org/10.1080/13683 500.2015.1119103.

Durbarry, R. (2004). Tourism and economic growth: The case of Mauritius. Tourism Economics, 10(4), 389-401. https://doi.org/10.5367/0000000042430962.

Ekanayake, E. M., Long, A. E. (2012). Tourism development and economic growth in developing countries. The International Journal of Business and Finance Research, 6(1), 61-63. Retrieved November 17, 2019, from https://papers.ssrn.com/sol3/papers.cfm?abstract_id=1948704.

Fareed, Z., Meo, M. S., Zulfiqar, B., Shahzad, F., \& Wang, N. (2018). Nexus of tourism, terrorism, and economic growth in Thailand: new evidence from asymmetric ARDL cointegration approach. Asia Pacific Journal of Tourism Research, 23(12), 1129-1141. https://doi.org/10.1080/10941665.2018.1528289.

Fereidouni, H. G., \& Al-mulali, U. (2014). The interaction between tourism and FDI in real estate in OECD countries. Current Issues in Tourism, 17(2), 105-113. https://doi.org/10.1080/13683500.2012.733359.

Gaidar, K., Aftab, A., Idris, E. A., Malik, O. J. (2016). The relationship between tourism, foreign direct investment and economic growth: Evidence from Saudi Arabia. European Academic Research, 4(4). Retrieved November 17, 2019, from www.euacademic.org.

Gorus, M. S., \& Aslan, M. (2019). Impacts of economic indicators on environmental degradation: Evidence from MENA countries CD. Renewable and Sustainable Energy Reviews, 103, 259-268. https://doi. org/10.1016/j.rser.2018.12.042.

Granger, C., \& Newbold, P. (1974). Spurious regressions in econometrics. Journal of Econometrics, 2(2), 111-120. Retrieved March 4, 2019, from https://econpapers.repec.org/article/eeeeconom/ v_3a2_3ay_3a1974_3ai_3a2_3ap_3a111-120.htm.

Granger, C. W. J., \& Yoon, G. (2002). Hidden cointegration. SSRN Electronic Journal. https://doi. org/10.2139/ssrn.313831.

Hakimi, A., \& Hamdi, H. (2016). Trade liberalization, FDI inflows, environmental quality and economic growth: A comparative analysis between Tunisia and Morocco. Renewable and Sustainable Energy Reviews, 58, 1445-1456. https://doi.org/10.1016/j.rser.2015.12.280.

Hatemi-J, A. (2008). Tests for cointegration with two unknown regime shifts with an application to financial market integration. Empirical Economics, 35(3), 497-505. https://doi.org/10.1007/s00181-007-0175-9.

HDIP. (2016). Pakistan energy yearbook 2015. Islamabad: Development Institute of Pakistan (HDIP).

Hossain, S. (2012). An econometric analysis for co2 emissions, energy consumption, economic growth, foreign trade and urbanization of Japan. Low Carbon Economy, 03(03), 92-105. https://doi.org/10.4236/ lce.2012.323013.

Hotelling, H. (1933). Analysis of a complex of statistical variables into principal components. Journal of Educational Psychology, 24(6), 417-441. https://doi.org/10.1037/h0071325.

IPCC. (2013). Intergovernmental panel on climate change (IPCC) climate change 2013: the physical science basis (technical summary with link to full report). Retrieved March 1, 2019, from https://europa.eu/ capacity4dev/unep/document/intergovernmental-panel-climate-change-ipcc-climate-change-2013physical-science-basis-tech.

IRENA. (2018). Renewables readiness assessment: Pakistan. Abu Dhabi: International Renewable Energy Agency (IRENA).

Isik, C., Dogru, T., \& Turk, E. S. (2018). A nexus of linear and non-linear relationships between tourism demand, renewable energy consumption, and economic growth: Theory and evidence. International Journal of Tourism Research, 20(1), 38-49. https://doi.org/10.1002/jtr.2151. 
Johansen, S. (1988). Statistical analysis of cointegration vectors. Journal of Economic Dynamics and Control, 12(2-3), 231-254. https://doi.org/10.1016/0165-1889(88)90041-3.

Jolliffe, I. T. (1986). Introduction. In I. T. Jolliffe (Ed.), Principal component analysis (pp. 1-7). New York: Springer.

Kaplan, M., \& Celik, T. (2008). The impact of tourism on economic performance: The case of Turkey. The International Journal of Applied Economics and Finance, 2(1), 13-18. https://doi.org/10.3923/ijaef .2008.13.18.

Katircioglu, S. T., Feridun, M., \& Kilinc, C. (2014). Estimating tourism-induced energy consumption and $\mathrm{CO}_{2}$ emissions: The case of Cyprus. Renewable and Sustainable Energy Reviews. https://doi. org/10.1016/j.rser.2013.09.004.

Khalil, S., Kakar, M. K., Waliullah, A., \& Malik, A. (2007). Role of tourism in economic growth: empirical evidence from pakistan economy. The Pakistan Development Review, 46, 985-995. https://doi. org/10.2307/41261208.

Khan, A., Chenggang, Y., Hussain, J., \& Bano, S. (2019). Does energy consumption, financial development, and investment contribute to ecological footprints in BRI regions? Environmental Science and Pollution Research. https://doi.org/10.1007/s11356-019-06772-w.

Khan, T. M., Gang, B., Fareed, Z., \& Khan, A. (2020). How does CEO tenure affect corporate social and environmental disclosures in China? Moderating role of information intermediaries and independent board. Environmental Science and Pollution Research. https://doi.org/10.1007/s11356-020-11315-9.

Khoshnevis Yazdi, S., Homa Salehi, K., \& Soheilzad, M. (2017). The relationship between tourism, foreign direct investment and economic growth: Evidence from Iran. Current Issues in Tourism, 20(1), 15-26. https://doi.org/10.1080/13683500.2015.1046820.

Koçak, E., Ulucak, R., \& Ulucak, Z. Ş. (2020). The impact of tourism developments on $\mathrm{CO}_{2}$ emissions: An advanced panel data estimation. Tourism Management Perspectives, 33, 100611. https://doi. org/10.1016/j.tmp.2019.100611.

Lee, J. W., \& Brahmasrene, T. (2013). Investigating the influence of tourism on economic growth and carbon emissions: Evidence from panel analysis of the European Union. Tourism Management, 38, 69-76. https://doi.org/10.1016/j.tourman.2013.02.016.

Lei, Z., \& Jing, G. (2016). Exploring the effects of international tourism on China's economic growth, energy consumption and environmental pollution: Evidence from a regional panel analysis. Renewable and Sustainable Energy Reviews, 53, 225-234. https://doi.org/10.1016/j.rser.2015.08.040.

Li, Y., Shi, X., \& Yao, L. (2016). Evaluating energy security of resource-poor economies: A modified principal component analysis approach. Energy Economics, 58, 211-221. https://doi.org/10.1016/j.eneco .2016.07.001.

Lin, C.-H., Wang, W.-C., Yeh, Y.-I., Lin, C.-H., Wang, W.-C., \& Yeh, Y.-I.E. (2019). Spatial distributive differences in residents' perceptions of tourism impacts in support for sustainable tourism developmentLu-Kang destination case. Environments, 6(1), 8. https://doi.org/10.3390/environments6010008.

Malik, M. I., \& Rehman, A. (2015). Choice of spectral density estimator in ng-perron test: A comparative analysis. International Econometric Review (IER), 7(2), 51-63. Retrieved February 24, 2019 from https://ideas.repec.org/a/erh/journl/v7y2015i2p51-63.html.

Mamipour, S., Yahoo, M., \& Jalalvandi, S. (2019). An empirical analysis of the relationship between the environment, economy, and society: Results of a PCA-VAR model for Iran. Ecological Indicators, 102, 760-769. https://doi.org/10.1016/J.ECOLIND.2019.03.039.

Meo, M. S., Chowdhury, M. A. F., Shaikh, G. M., Ali, M., \& Masood Sheikh, S. (2018). Asymmetric impact of oil prices, exchange rate, and inflation on tourism demand in Pakistan: new evidence from nonlinear ARDL. Asia Pacific Journal of Tourism Research, 23(4), 408-422. https://doi.org/10.1080/10941 665.2018.1445652.

Naz, S., Sultan, R., Zaman, K., Aldakhil, A. M., Nassani, A. A., \& Abro, M. M. Q. (2019). Moderating and mediating role of renewable energy consumption, FDI inflows, and economic growth on carbon dioxide emissions: Evidence from robust least square estimator. Environmental Science and Pollution Research, 26(3), 2806-2819. https://doi.org/10.1007/s11356-018-3837-6.

Nepal, R., Indra al Irsyad, M., \& Nepal, S. K. (2019). Tourist arrivals, energy consumption and pollutant emissions in a developing economy-implications for sustainable tourism. Tourism Management, 72(2018), 145-154. https://doi.org/10.1016/j.tourman.2018.08.025.

Ng, S., \& Perron, P. (2001). Lag length selection and the construction of unit root tests with good size and power. Econometrica, 69, 1519-1554. https://doi.org/10.2307/2692266.

Obradović, S., \& Lojanica, N. (2017). Energy use, $\mathrm{CO}_{2}$ emissions and economic growth-causality on a sample of SEE countries. Economic Research-Ekonomska Istraživanja, 30(1), 511-526. https://doi. org/10.1080/1331677X.2017.1305785. 
Ohlan, R. (2017). The relationship between tourism, financial development and economic growth in India. Future Business Journal, 3(1), 9-22. https://doi.org/10.1016/j.fbj.2017.01.003.

Parrilla, J. C., Font, A. R., \& Nadal, J. R. (2007). Tourism and long-term growth a Spanish perspective. Annals of Tourism Research, 34(3), 709-726. https://doi.org/10.1016/j.annals.2007.02.003.

Payne, J. E., \& Mervar, A. (2010). The tourism-growth nexus in Croatia. Tourism Economics, 16(4), 1089-1094. https://doi.org/10.5367/te.2010.0014.

Pesaran, M. H., Shin, Y., \& Smith, R. P. (1999). Pooled mean group estimation of dynamic heterogeneous panels. Journal of the American Statistical Association, 94(446), 621. https://doi. org/10.2307/2670182.

Pesaran, M. H., Shin, Y., \& Smith, R. J. (2001). Bounds testing approaches to the analysis of level relationships. Journal of Applied Econometrics, 16(3), 289-326. https://doi.org/10.1002/jae.616.

Rahman, M. M., \& Kashem, M. A. (2017). Carbon emissions, energy consumption and industrial growth in Bangladesh: Empirical evidence from ARDL cointegration and Granger causality analysis. Energy Policy, 110, 600-608. https://doi.org/10.1016/j.enpol.2017.09.006.

Raza, S. A., \& Jawaid, S. T. (2013). Terrorism and tourism: A conjunction and ramification in Pakistan. Economic Modelling, 33, 65-70. https://doi.org/10.1016/j.econmod.2013.03.008.

Ridderstaat, J., Croes, R., \& Nijkamp, P. (2014). Tourism and long-run economic growth in Aruba. International Journal of Tourism Research, 16(5), 472-487. https://doi.org/10.1002/jtr.1941.

Sapkota, P., \& Bastola, U. (2017). Foreign direct investment, income, and environmental pollution in developing countries: Panel data analysis of Latin America. Energy Economics, 64(C), 206-212. https://doi.org/10.1016/j.eneco.2017.04.001.

Seker, F., Ertugrul, H. M., \& Cetin, M. (2015). The impact of foreign direct investment on environmental quality: A bounds testing and causality analysis for Turkey. Renewable and Sustainable Energy Reviews, 52, 347-356. https://doi.org/10.1016/J.RSER.2015.07.118.

Selvanathan, S., Selvanathan, E. A., \& Viswanathan, B. (2012). Causality between foreign direct investment and tourism: Empirical evidence from India. Tourism Analysis. https://doi.org/10.3727/10835 $4212 X 13330406124296$.

Shah, W. U. H., Yasmeen, R., \& Padda, I. U. H. (2019). An analysis between financial development, institutions, and the environment: A global view. Environmental Science and Pollution Research, 26(21), 21437-21449. https://doi.org/10.1007/s11356-019-05450-1.

Shahbaz, M., Hye, Q. M. A., Tiwari, A. K., \& Leitão, N. C. (2013). Economic growth, energy consumption, financial development, international trade and $\mathrm{CO}_{2}$ emissions in Indonesia. Renewable and Sustainable Energy Reviews, 25, 109-121. https://doi.org/10.1016/J.RSER.2013.04.009.

Shaheen, K., Zaman, K., Batool, R., Khurshid, M. A., Aamir, A., Shoukry, A. M., et al. (2019). Dynamic linkages between tourism, energy, environment, and economic growth: evidence from top 10 tourism-induced countries. Environmental Science and Pollution Research. https://doi.org/10.1007/ s11356-019-06252-1.

Shakouri, B., Khoshnevis Yazdi, S., \& Ghorchebigi, E. (2017). Does tourism development promote $\mathrm{CO}_{2}$ emissions? Anatolia, 28(3), 444-452. https://doi.org/10.1080/13032917.2017.1335648.

Shin, Y., Yu, B., \& Greenwood-Nimmo, M. (2014). Modelling asymmetric cointegration and dynamic multipliers in a nonlinear ARDL Framework. Festschrift in Honor of Peter Schmidt (pp. 281-314). New York: Springer.

Siddiqui, F., Siddiqui, D. A. (2019). Causality between tourism and foreign direct investment: An empirical evidence from Pakistan. Asian Journal of Economic Modeling, 7(1), 27-44. Retrieved November 20, 2019, from https://ideas.repec.org/a/asi/ajemod/2019p27-44.html.

Solarin, S. A. (2014). Tourist arrivals and macroeconomic determinants of $\mathrm{CO}_{2}$ emissions in Malaysia. Anatolia, 25(2), 228-241. https://doi.org/10.1080/13032917.2013.868364.

Srinivasan, P., Kumar, P. K. S., \& Ganesh, L. (2012). Tourism and economic growth in Sri Lanka. Environment and Urbanization ASIA, 3(2), 397-405. https://doi.org/10.1177/0975425312473234.

Sun, X., Chenggang, Y., Khan, A., Hussain, J., \& Bano, S. (2020). The role of tourism, and natural resources in the energy-pollution-growth nexus: an analysis of belt and road initiative countries. Journal of Environmental Planning and Management. https://doi.org/10.1080/09640 568.2020.1796607.

Surugiu, C., \& Surugiu, M. R. (2013). Is the tourism sector supportive of economic growth? Empirical evidence on Romanian tourism. Tourism Economics, 19(1), 115-132. https://doi.org/10.5367/ te.2013.0196.

Tang, C. F. (2011). Is the tourism-led growth hypothesis valid for Malaysia? A view from disaggregated tourism markets. International Journal of Tourism Research, 13(1), 97-101. https://doi. org/10.1002/jtr.807. 
Tang, C. F., \& Abosedra, S. (2014). Small sample evidence on the tourism-led growth hypothesis in Lebanon. Current Issues in Tourism, 17(3), 234-246. https://doi.org/10.1080/13683500.2012.732044.

Tang, C. F., \& Tan, E. C. (2013). How stable is the tourism-led growth hypothesis in Malaysia? Evidence from disaggregated tourism markets. Tourism Management, 37, 52-57. https://doi.org/10.1016/j.tourm an.2012.12.014.

Tang, C., Zhong, L., \& Ng, P. (2017). Factors that influence the tourism industry's carbon emissions: A tourism area life cycle model perspective. Energy Policy, 109, 704-718. https://doi.org/10.1016/j.enpol 2017.07.050.

Tiba, S., Omri, A., \& Frikha, M. (2016). The four-way linkages between renewable energy, environmental quality, trade and economic growth: A comparative analysis between high and middle-income countries. Energy Systems, 7(1), 103-144. https://doi.org/10.1007/s12667-015-0171-7.

Tsai, K., Lin, T., Hwang, R., \& Huang, Y. (2014). Carbon dioxide emissions generated by energy consumption of hotels and homestay facilities in Taiwan. Tourism Management, 42, 13-21. https://doi. org/10.1016/j.tourman.2013.08.017.

Uchiyama, K. (2016). Environmental Kuznets curve hypothesis and carbon dioxide emissions. Tokyo: Springer,. https://doi.org/10.1007/978-4-431-55921-4.

UN. (2017). The sustainable development goals. https://unstats.un.org/sdgs/report/2017/.

UNWTO. (2008). Climate change and tourism-responding to global challenges I sustainable development of tourism. Retreived February 24, 2019, from http://sdt.unwto.org/news/2011-08-16/climate-chang e-and-tourism-responding-global-challenges.

Vanegas, M., \& Croes, R. R. (2003). Growth, development and tourism in a small economy: Evidence from Aruba. International Journal of Tourism Research, 5(5), 315-330. https://doi.org/10.1002/jtr.441.

Vellas, F. (2007). Économie et politique du tourisme international. Economica.

World Bank. (2018). World development indicators (WDI) I Data Catalog. World Bank. Retrieved January 31, 2019, from https://datacatalog.worldbank.org/dataset/world-development-indicators.

World Travel and Tourism Council. (2018). Travel and Tourism Impact 2018 Pakistan. United Kingdom. https://www.wttc.org/-/media/files/reports/economic-impact-research/countries-2018/pakistan20 18.pdf.

Zaman, K., Bin Abdullah, A., Khan, A., Bin Mohd Nasir, M. R., Hamza, T. A. A. T., \& Hussain, S. (2016a). Dynamic linkages among energy consumption, environment, health and wealth in BRICS countries: Green growth key to sustainable development. Renewable and Sustainable Energy Reviews, 56, 12631271. https://doi.org/10.1016/j.rser.2015.12.010.

Zaman, K., Khan, M. M., \& Ahmad, M. (2011). Exploring the relationship between tourism development indicators and carbon emissions: A case study of Pakistan. World Applied Sciences Journal, 15(5), 690-701. Retrieved April 30, 2019, from https://pdfs.semanticscholar.org/b890/96fb330d6330818 724100f5a81e3a980cfb9.pdf.

Zaman, K., Shahbaz, M., Loganathan, N., \& Raza, S. A. (2016b). Tourism development, energy consumption and environmental Kuznets Curve: Trivariate analysis in the panel of developed and developing countries. Tourism Management, 54, 275-283. https://doi.org/10.1016/J.TOURMAN.2015.12.001.

Zhang, S., \& Liu, X. (2019). The roles of international tourism and renewable energy in environment: New evidence from Asian countries. Renewable Energy. https://doi.org/10.1016/J.RENENE.2019.02.046.

Zhou, S., Huang, Y., Yu, B., \& Wang, G. (2015). Effects of human activities on the eco-environment in the middle Heihe river basin based on an extended environmental Kuznets curve model. Ecological Engineering, 76, 14-26. https://doi.org/10.1016/J.ECOLENG.2014.04.020.

Zivot, E., \& Andrews, D. W. K. (1992). Further evidence on the great crash, the oil-price shock, and the unit-root hypothesis. Journal of Business and Economic Statistics, 10(3), 251. https://doi. org/10.2307/1391541.

Publisher's Note Springer Nature remains neutral with regard to jurisdictional claims in published maps and institutional affiliations. 